PROCEEDINGS OF THE

TWENTY-NINTH INTERNATIONAL

MATADOR

CONFERENCE 


\section{PROCEEDINGS OF THE \\ TWENTY-NINTH INTERNATIONAL \\ MATADOR \\ CONFERENCE}

held in Manchester

6th-7th April 1992

Edited by

J. ATKINSON, G. BARROW, M. BURDEKIN, N.R. CHITKARA and R.G. HANNAM

Division of Manufacturing and Machine Tools

Department of Mechanical Engineering

UMIST

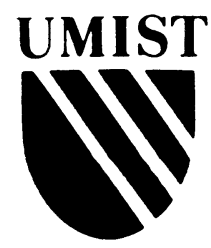

Macmillan Education

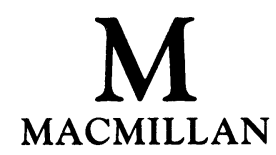


(C) Department of Mechanical Engineering

University of Manchester Institute of Science and Technology 1992

Softcover reprint of the hardcover 1st edition 1992 978-0-333-55317-6

1992

All rights reserved. No reproduction, copy or transmission of this publication may be made without written permission.

No paragraph of this publication may be reproduced, copied or transmitted save with written permission or in accordance with the provisions of the Copyright, Designs and Patents Act 1988, or under the terms of any licence permitting limited copying issued by the Copyright Licensing Agency, 90 Tottenham Court Road, London W1P 9HE.

Any person who does any unauthorised act in relation to this publication may be liable to criminal prosecution and civil claims for damages.

First published 1992 by the Department of Mechanical Engineering

UMIST

P.O. Box 88, Manchester M60 1QD

in association with

THE MACMILLAN PRESS LTD

Houndmills, Basingstoke, Hampshire RG21 2XS

and London

Companies and representatives

throughout the world

ISBN 978-1-349-12435-0

ISBN 978-1-349-12433-6 (eBook)

DOI 10.1007/978-1-349-12433-6

A catalogue record for this book is available from the British Library

Page make-up: Mellor Print, Marple, Cheshire 


\title{
TWENTY-NINTH INTERNATIONAL
}

MATADOR

\section{CONFERENCE}

6th-7th April 1992

\section{ORGANIZING AND REVIEWING COMMITTEE}

\author{
Dr. J. Atkinson \\ Dr. G. Barrow \\ Dr. P. Brunn \\ Dr. M. Burdekin \\ Dr. N.R. Chitkara \\ Dr. R.G. Hannam
}

ORGANIZING SECRETARY

R. Kirk 


\title{
CONTENTS
}

\section{CADCAM FOR THE 1990s}

\author{
Chairman: Dr. J. ATKINSON
}

An investigation of object-oriented concepts in feature based design

M.N. LATIF and R.G. HANNAM

Facilities embodied in a new computer aided logical design system

W.L.D. WONG and J. ATKINSON

Creating CAD models from physical parts

A. J. MEDLand, G. MULLINEUX and R. SINGH

A simplified approach towards the automatic machining of $21 / 2 \mathrm{D}$ components using a solid modeller J.L. MURRAY, Y. YUE and J. CORNEY

Feature-based planning data model for generative planning systems

N.N.Z. GINDY and S.X. HUANG

Advances in CAD-CAM integration

C. MARTY, M. CHAABANE and B. ROUMESY

A1 based CAPP methods integrated into a CAPP environment

H. ROZENFELD, S.R. RODRIGUES and J.F.G. DE OLIVEIRA

Structure and capability description of machine tools: A linguistic approach

T.M. RATCHEV and N.N.Z. GINDY

The development and practice of the CAD/CAPP/CAM integrated system of feature-based modelling

PENG QINGJIN, LIANG LIANSHENG, ZHAO RUJIA and XU QINGYOU

Cooperating expert systems for CADCAM

J.A. BRANDON AND G.Q. HUANG

A knowledge based intelligent CAD system for cold forging design using fuzzy theory

T. HIRAI, K. HARA, T. KATAYAMA ET AL

Interactive programme system for determining the optimum machining tolerances having regard to assembly requirements

T. TÓTH

Improving the manufacturing process in the aircraft industry via real time $\mathrm{NC}$ tape verification

M.N. BRADSHAW, D.K. HARRISON and T.S. BAINES

CAE in sheet forming

$$
\text { V. STOILJKOVIĆ }
$$

Production of 3 dimensional shapes using computational electro discharge machining (EDM)

M. BAYRAMOGLU and A.W. DUFFILL 


\title{
FMS, CIM AND ROBOTICS
}

\author{
Chairman: Dr. R.G. HANNAM
}

CADEXCAP and INSPEX: The integration of expert process planning machining and inspection for rotational parts

M. KALTA, X.Q. TANG and B.J. DAVIES

Integrated information systems for island structures

V. HORNUNG

The design of quality assurance system in the environment of CIMS

XU QINGYOU, ZHAO RUJIA and CHEN XI

Natural integration levels of the process planning function

J. CHRISTENSEN and N.E. LARSEN

Applications of back propagation neural networks to robot position control

C. LEE

The application of the finite elements method to the structural design of a five axis low cost industrial robot

J.M. PEREIRA DIAS and P.E.L. BARBOSA RODRIGUES

Robot cell-control in an uncertain environment using constraint modelling techniques

R.T. RAKOWSKI, G. MULLINEUX and A.W. ANSARI

Performance assessment of a robot for use in a fabric test cell

V.V.P. POTLURI, J. ATKINSON and I. PORAT

It's time to tackle the hidden inventories

J.M. LEVY

Strategies for exploiting emerging programming philosophies to re-invigorate group technology

J.A. BRANDON and H. SCHÄFER

Production scheduling under JIT constraints

E. GENTILI, D.K. HARRISON, M. BRAGLIA and H. BERA

Manufacturing management sytem requirements of small firms

H. KARIMABADY and P.J. BRUNN

A message from 100 FMS-projects for industry

H.-J. WARNECKE, R. STEINHILPER and H. STORN

FMS architecture for an optimum quality and process reactivity

C. DOITEAUX, B. ROCHOTTE, E. BAJIC and J. RICHARD

A new approach to the automatic design of FMS through a simple but effective forecast of production needs

F. CHESI and Q. SEMERARO

Strategic perspectives for implementation of FMS, Robotics and CIM

J.A. BRANDON 


\section{MANUFACTURING METROLOGY}

Chairman: Dr. M. BURDEKIN

Design and development of high performance structures for coordinate measuring machines

C. STOTT

Measurement and compensation of thermal error on a machining center

K.C. FAN, J.F. LIN and S.S. LU

Improving the accuracy of $\mathrm{CNC}$ machine tools using software compensation for thermally

induced errors

B.R. HARDWICK

Parameter identification of geometric elements from digitized data of coordinate measuring machines

J.P. KRUTH and WEIYIN MA

Study on the thermal behaviour of machine tools and its improving strategies

ZHAO RUJIA, PENG QINGJIN, XU QINGYOU and YAO GONGQI

"Right diameter-first cut" lathe datuming probe

F. NICKOLS and K.F. MARTIN

Analysis of machining error distributions in end milling

K. SHIRASE, T. INAMURA, and T. YASUI

A laser system for in-process analysis of planarity

G.L. BRAGLIA, C. OLEARI, R. REVERBERI, M. BRAGLIA and E. GENTILI

Automatic recognition for the bearing of scraped surfaces by image process techniques

K. MITSUI and K. NOMURA

The selection of surfaces in inspection planning for coodinate measuring machines

J.L.H. HSU, N.P. JUSTER and A. DE PENNINGTON

An approach to feature-based inspection planning

S.S.G. LEE and L.P. KHOO

An intelligent link between CAD and automatic inspection

J.H. HASSAN, A.J. MEDLAND, G. MULLINEUX and E. SITTAS

An intelligent inspection planning environment linked to feature-based geometric modeller

P.Y. JIANG, R.J. ZHAO and Q.Q. CHU

Development and application of integrated calibration software for the HP laser interferometer

A. BUTTERWORTH and M. BURDEKIN

Experiments on monoplane camera calibration accuracy

G. CHIORBOLI, C. MORANDI and M. VASCOTTO

High speed automatic testing of threaded components

O. BASMAGE, M.A. EL BARADIE and M.S.J. HASHMI

Optimising the contouring accuracy of $\mathrm{CNC}$ machines using the Contisure system

M. BURDEKIN and W. JYWE 


\section{METAL FORMING}

Chairman: Dr. N.R. CHITKARA

Ageing characteristics of 2024 aluminium alloy

R.A. SIDDIQUI

The effects of titanium nitride coated tools in the deep drawing of mild steel sheets

K.S. LEE and K.H.W. SEAH

Statistical process control in pressure die-casting

A.J. WILKINSON, J.A. SCOTT, G.E. WILSON, and A. CONNOR

Increasing the adaptability of high alloyed steels in plastic deformation techniques

C.C. SZILVASSY and W.C.K. WONG

Analysis of open die forging

B. AKSAKAL, F.H. OSMAN and A.N. BRAMLEY

Economical manufacturing of gearwheels by near net shape forging

E. DOEGE, J. THALEMANN and F. WEBER

An extrusion forging study with improved die geometry

G. MACCARINI, C. GIARDINI, G. PELLEGRINI, E. CERETTI and A. BUGINI

Deformation of rectangular billets between dies with unparallel grooves

W. HU and M.S.J. HASHMI

Limits of the open-die forward extrusion: Numerical analysis and experimental tests

L. CANNIZZARO, F. MICARI and R. RICCOBONO

A feasibility study on explosive 'form-cladding'

K. RAGHU KANDAN, M. RATINASABAPATHI and P.V. VAIDYANATHAN

Optimization of shrink ring interference for metal forming dies

T. HIRAI, T. KATAYAMA and K. AKAMATSU

Closed-die forging of some axi-symmetric shaft and rib-type components with asymmetry about another axis

N.R. CHITKARA and S.D.K. BARBAT

Rolling of channel section beams in three passes: An experimental investigation of roll load, torque and geometry changes 


\section{CUTTING TECHNOLOGY}

Chairman: Dr. G. BARROW

Development of EDM monitoring system using neural networks

Y. KONISHI, M. HASEGAWA and I. SUGIMOTO

A PC-based in-process tool wear monitoring system

K.S. LEE, S.C. TEO and L.C. LEE

The use of thermography for tool wear monitoring

K.F. HALE and B.E. JONES

Data acquisition, signal processing and mathematical modelling strategies for in process condition monitoring

J. BRANDON and Z. BINGLIN

A study on chip curling and breaking

P.D. LIU, R.S. HU, H.T. ZHANG and X.S. WU

The design and development of automatic chip breaking for continuous cutting operations

G.T. SMITH

Fine and/or finish machining of cold worked steel in near-net-shape manufacturing processes

J. KOPAČ, D. ZALAR and K. KUZMAN

Tool life of coated end milling cutters

M.A. MANNAN, L. WESTIN and P. SVENSSON

Electric discharge machining of small holes through polycrystalline diamond wire drawing blanks

T. LE ROUX, M.L.H. WISE, D.K. ASPINWALL and L. BLUNT

A method for the design of forming cutters for machining modified involute helical gears

C. LEE and D.C. XIAO

Grinding process dominance by means of the dressing operation

J.F.G. DE OLIVEIRA, B.DE.M. PURQUERIO, R.T. COELHO and E.C. BIANCHI

Analysis of scraping process (The applied force to and the movement of scraper)

H. FUJII, H. SHIMAZU, P. LAKAWATHANA, M. ASAI, N. SASE and T. KATO

An experimental investigation of temperatures in chip formation

H.T. YOUNG

Modelling of final plastic deformation in the case of continuous straight-edged oblique cutting

W. GRZESIK and J. LITWIN

On the depth of subsurface plastic deformation produced by peripheral milling operation

A-K.A. RADHWAN and M.Y. AL-MAKKY

Estimation of the mean strain rate in the orthogonal machining of metals

J. CHAKRABARTY and R.A. SIDDIQUI 


\section{Foreword}

It is a pleasure to introduce to you the proceedings of the 29th International MATADOR Conference.

The new format of the 'MATADOR' Conference is now firmly established and it is a measure of its success that we have had over 150 papers submitted for consideration of which 77 were finally selected for presentation in the five distinctly separate conferences of CADCAM for the 1990s, FMS CIM and Robotics, Manufacturing Metrology, Metal Forming and Cutting Technology.

1992 is also the 25th anniversary of the first FMS. It was at the 1967 MATADOR Conference that Dr. Theo Williamson announced the Molins System 24 to the world by presenting a substantial paper which covered the system's design, philosophy and economics. The 29th International MATADOR Conference chooses to mark this anniversary by a special session under the heading: The Silver Jubilee of the Molins System 24 - the first FMS.

We hope and expect that you will find much to interest you in the following pages and in the discussions you will have during the Conference with your colleagues from the many countries represented.

The Organizing Committee 